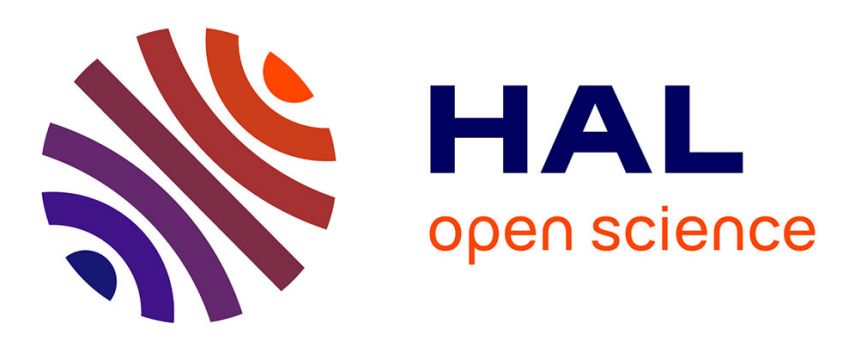

\title{
Temperature-dependent rate constants for the reactions of chlorine atom with methanol and $\mathrm{Br} 2$
}

Yuri Bedjanian

\section{To cite this version:}

Yuri Bedjanian. Temperature-dependent rate constants for the reactions of chlorine atom with methanol and $\mathrm{Br} 2$. International Journal of Chemical Kinetics, 2020, 52 (5), pp.310-318. 10.1002/kin.21351 . hal-02511712

\section{HAL Id: hal-02511712 \\ https://hal.science/hal-02511712}

Submitted on 3 Dec 2020

HAL is a multi-disciplinary open access archive for the deposit and dissemination of scientific research documents, whether they are published or not. The documents may come from teaching and research institutions in France or abroad, or from public or private research centers.
L'archive ouverte pluridisciplinaire HAL, est destinée au dépôt et à la diffusion de documents scientifiques de niveau recherche, publiés ou non, émanant des établissements d'enseignement et de recherche français ou étrangers, des laboratoires publics ou privés. 


\title{
Temperature Dependent Rate Constants for the Reactions of Chlorine Atom with Methanol and $\mathrm{Br}_{2}$
}

\author{
Yuri Bedjanian \\ Institut de Combustion, Aérothermique, Réactivité et Environnement (ICARE), CNRS, 45071 \\ Orléans Cedex 2, France
}

\begin{abstract}
Kinetics of the reaction of $\mathrm{Cl}$ atoms with methanol has been investigated at 2 Torr total pressure of helium and over a wide temperature range $225-950 \mathrm{~K}$, using a discharge flow reactor combined with an electron impact ionization quadrupole mass spectrometer. The rate constant of the reaction $\mathrm{Cl}+\mathrm{CH}_{3} \mathrm{OH} \rightarrow$ products (1) was determined using both absolute measurements under pseudo-first order conditions, monitoring the kinetics of $\mathrm{Cl}$ atom consumption in excess of methanol and relative rate method, $k_{1}=(5.1 \pm 0.8) \times 10^{-11} \mathrm{~cm}^{3}$ molecule $\mathrm{s}^{-1}$, and was found to be temperature independent over the range $\mathrm{T}=225-950 \mathrm{~K}$. The rate constant of the reaction $\mathrm{Cl}+\mathrm{Br}_{2} \rightarrow \mathrm{BrCl}+\mathrm{Br}$ (3) was measured in an absolute way monitoring $\mathrm{Cl}$-atom decays in excess of $\mathrm{Br}_{2}: k_{3}=1.64 \times 10^{-10} \exp (34 / \mathrm{T}) \mathrm{cm}^{3}$ molecule ${ }^{-1} \mathrm{~s}^{-1}$ at $\mathrm{T}=$ $225-960 \mathrm{~K}$ (with conservative 15\% uncertainty). The experimental data for $k_{3}$ can also be adequately represented by the temperature independent value of $k_{3}=(1.8 \pm 0.3) \times 10^{-10} \mathrm{~cm}^{3}$ molecule $\mathrm{s}^{-1}$. The kinetic data from the present study are compared with previous measurements.
\end{abstract}

Keywords: $\mathrm{Cl}, \mathrm{CH}_{3} \mathrm{OH}, \mathrm{Br}_{2}$, kinetics, rate coefficient.

Correspondence to: Yuri Bedjanian: Tel.: +33 238255474, e-mail: yuri.bedjanian@cnrs-orleans.fr Supporting Information is available in the online issue at www.wileyonlinelibrary.com. 


\section{INTRODUCTION}

Methanol $\left(\mathrm{CH}_{3} \mathrm{OH}\right)$ is a smallest representative of alcohols, chemical species belonging to a large family of Oxygenated Volatile Organic Compounds playing an important role in the tropospheric chemistry. ${ }^{1} \mathrm{CH}_{3} \mathrm{OH}$ is one of the most abundant volatile organic species in the atmosphere due to important biogenic emissions and in situ production in atmospheric oxidation of methane and other organic compounds. ${ }^{2}$ Atmospheric degradation of methanol is triggered mainly by its reaction with $\mathrm{OH}$ radicals, ${ }^{1}$ however contribution of the reaction with $\mathrm{Cl}$ atoms can be significant in certain locations with elevated concentration of $\mathrm{Cl}^{3-5} \mathrm{Cl}-$ atom reaction with $\mathrm{CH}_{3} \mathrm{OH}$ is a well-known and very often used in laboratory source of $\mathrm{CH}_{2} \mathrm{OH}$ and, in the presence of $\mathrm{O}_{2}$, of $\mathrm{HO}_{2}$ radicals:

$$
\begin{aligned}
& \mathrm{Cl}+\mathrm{CH}_{3} \mathrm{OH} \rightarrow \mathrm{CH}_{2} \mathrm{OH}+\mathrm{HCl} \\
& \mathrm{Cl}+\mathrm{CH}_{3} \mathrm{OH} \rightarrow \mathrm{CH}_{3} \mathrm{O}+\mathrm{HCl} \\
& \mathrm{CH}_{2} \mathrm{OH}+\mathrm{O}_{2} \rightarrow \mathrm{HO}_{2}+\mathrm{CH}_{2} \mathrm{O}
\end{aligned}
$$

Hence, the information on kinetics and products of $\mathrm{Cl}$ reaction with methanol in an extended temperature range is of interest also for laboratory studies of other reactions important in atmospheric and combustion chemistry.

Kinetics of the reaction

$$
\mathrm{Cl}+\mathrm{CH}_{3} \mathrm{OH} \rightarrow \text { products }
$$

has been extensively studied using both absolute and relative rate methods. ${ }^{6-18}$ Room temperature data for the reaction rate constant from different studies are consistent with each other; ${ }^{7-15}$ however the temperature dependence of the rate constant is not well established. ${ }^{6,16-18}$ As noted in a most recent temperature dependent study of reaction (1), "additional experiments that cover temperatures both below and above room temperature are needed for further assessment." ${ }^{18}$ In this regard, the objective of the present work was to measure the rate constant of reaction (1) in a wide temperature range in order to harmonize existing experimental data on temperature dependence of $k_{1}$.

In addition, the rate constant of the reaction of $\mathrm{Cl}$ atoms with $\mathrm{Br}_{2}$ was measured as a part of this study. In the present work, this reaction was used for indirect detection of $\mathrm{Cl}$ by mass spectrometry via conversion of $\mathrm{Cl}$-atom to $\mathrm{BrCl}$ and as a reference reaction in the relative measurements of $k_{1}$ :

$$
\mathrm{Cl}+\mathrm{Br}_{2} \quad \rightarrow \quad \mathrm{BrCl}+\mathrm{Br}
$$


Previously, the reaction rate constant was measured only at relatively low temperatures $(T<$ 400K): the available data for $k_{3}$ are spread within a factor of $1.4 .{ }^{19-23}$ In the present work, we report the measurements of the rate constant in an extended temperature range, $T=225-$ $960 \mathrm{~K}$

\section{EXPERIMENTAL}

Experiments have been conducted at total pressure of 2 Torr of Helium using a conventional fast-flow reactor combined with a molecular beam sampling electron-impact ionization mass spectrometer. ${ }^{22,24-26}$ Depending on the temperature range two different flow reactors were used. Low temperature reactor, used at $T=225-320 \mathrm{~K}$, consisted of a Pyrex tube $(45 \mathrm{~cm}$ length and $2.4 \mathrm{~cm}$ i.d.) surrounded by a jacket through which a thermostated ethanol was circulated (Figure S1, Supporting Information (SI)). To reduce the heterogeneous loss of $\mathrm{Cl}$, the inner surface of the reactor as well as of the movable injector of $\mathrm{Cl}$ atoms was coated with halocarbon wax. High temperature reactor, used at $\mathrm{T}=335-960 \mathrm{~K}$, consisted of a Quartz tube $(45 \mathrm{~cm}$ length and $2.5 \mathrm{~cm}$ i.d.) with an electrical heater and water-cooled attachments (Figure S2, SI). ${ }^{26}$

Chlorine atoms were generated by dissociation of $\mathrm{Cl}_{2}$, diluted in $\mathrm{He}$, in a microwave discharge and introduced into the main reactor through the movable injector as shown in Figures S1 and S2 (SI). Three methods were used for the detection of chlorine atoms. Firstly, $\mathrm{Cl}$ atoms were detected at their parent peaks at $\mathrm{m} / \mathrm{z}=35 / 37\left(\mathrm{Cl}^{+}\right)$. In this case, the contribution at these peaks of $\mathrm{Cl}_{2}$ (precursor of $\mathrm{Cl}$ atoms) and chlorinated products of reactions (1) and (3) due to their fragmentation in the ion source of the mass spectrometer (always operating at ca. $25 \mathrm{eV}$ ) should be taken into account. In another method, $\mathrm{Cl}$ atoms were monitored at $\mathrm{m} / \mathrm{z}=114 / 116 / 118\left(\mathrm{BrCl}^{+}\right)$after being scavenged with an excess of $\mathrm{Br}_{2}$ $\left(\left[\mathrm{Br}_{2}\right] \approx 3 \times 10^{13}\right.$ molecule $\mathrm{cm}^{-3}$, added in the end of the reactor $5 \mathrm{~cm}$ upstream of the sampling cone, as shown in Figure S2 (SI)) in reaction 3:

$$
\begin{aligned}
& \mathrm{Cl}+\mathrm{Br}_{2} \rightarrow \mathrm{BrCl}+\mathrm{Br} \\
& k_{3}=1.64 \times 10^{-10} \exp (34 / \mathrm{T}) \mathrm{cm}^{3} \text { molecule }^{-1} \mathrm{~s}^{-1}(\mathrm{~T}=225-960 \mathrm{~K} \text {, this work }) .
\end{aligned}
$$

This method of $\mathrm{Cl}$-atom detection is free of the possible complications which may arise from the fragmentation of the chlorinated species in the ion source. It can also be noted that the concentration of $\mathrm{BrCl}$ is not affected by side reactions, for example, with organic radicals 
formed in reaction (1), since they are rapidly removed by $\mathrm{Br}_{2}$, which is present in the reaction system in high concentrations. Finally, $\mathrm{Cl}$ atoms were detected also at $\mathrm{m} / \mathrm{z}=$ $162 / 164\left(\mathrm{ICl}^{+}\right)$upon their titration with an excess of $\mathrm{I}_{2}\left(\left[\mathrm{I}_{2}\right]=(1.0-1.5) \times 10^{13}\right.$ molecule $\mathrm{cm}^{-3}$, added in the end of the reactor (Figures S1 and S2, SI): ${ }^{27}$

$$
\begin{aligned}
& \mathrm{Cl}+\mathrm{I}_{2} \quad \rightarrow \quad \mathrm{ICl}+\mathrm{I} \\
& k_{4}=(2.1 \pm 0.3) \times 10^{-10} \mathrm{~cm}^{3} \text { molecule } \mathrm{c}^{-1}(\mathrm{~T}=296-365 \mathrm{~K}) .
\end{aligned}
$$

The absolute concentrations of $\mathrm{Cl}$ atoms were determined using their chemical conversion to $\mathrm{BrCl}$ in reaction (3) with an excess of $\mathrm{Br}_{2}:[\mathrm{Cl}]=[\mathrm{BrCl}]=\Delta\left[\mathrm{Br}_{2}\right]$. The absolute calibrations of MS signals of the stable species $\left(\mathrm{CH}_{3} \mathrm{OH}, \mathrm{Br}_{2}, \mathrm{Cl}_{2}\right.$ and $\left.\mathrm{O}_{2}\right)$ were derived from measured flows of known mixtures of the species with helium.

The purities of the gases used were as follows: He (99.9999\%, Alphagaz), passed through liquid nitrogen trap; $\mathrm{O}_{2}$ (99.999\%, Alphagaz); $\mathrm{Br}_{2}$ (>99.99\%, Aldrich); $\mathrm{Cl}_{2}$ (>99\%, Ucar); $\mathrm{I}_{2}$ (99.999\%, Aldrich); methanol (> 99.9\%, Aldrich).

\section{RESULTS AND DISCUSSION}

\subsection{Rate constant of reaction (1): absolute measurements}

Experiments were carried out under pseudo-first order conditions monitoring kinetics of $\mathrm{Cl}$ consumption $\left([\mathrm{Cl}]_{0}=(1-2) \times 10^{11}\right.$ molecule $\left.\mathrm{cm}^{-3}\right)$ in an excess of methanol (see Table 1 for the concentrations of $\mathrm{CH}_{3} \mathrm{OH}$ used). It was observed that generally the consumption of $\mathrm{CH}_{3} \mathrm{OH}$ was insignificant due to its sufficiently high excess over $\mathrm{Cl}$ atoms. Under such conditions, $[\mathrm{Cl}]=[\mathrm{Cl}]_{0} \times \exp \left(-k_{1}{ }^{\prime} \times \mathrm{t}\right)$, with pseudo-first-order rate constant $k_{1}{ }^{\prime}=k_{1} \times\left[\mathrm{CH}_{3} \mathrm{OH}\right]+k_{\mathrm{w}}$, where $k_{\mathrm{w}}$ represents the loss of $\mathrm{Cl}$-atom in the absence of methanol in the reactor. Figure 1 displays examples of the exponential decays of $\mathrm{Cl}$-atoms in the presence of different concentrations of $\mathrm{CH}_{3} \mathrm{OH}$ in the reactor. Examples of second-order plots observed at different temperatures are shown in Figure 2. All the pseudo-first order rate constants, $k_{1}{ }^{\prime}$, were corrected for axial and radial diffusion of $\mathrm{Cl}$ atoms ${ }^{28}$ with diffusion coefficient of $\mathrm{Cl}$ in He calculated as $D_{0}=504 \times(\mathrm{T} / 298)^{1.85} \mathrm{Torr}_{\mathrm{cm}}^{-2} \mathrm{~s}^{-1}{ }^{29}$ The corrections were typically within a few percent, being somewhat higher in a few kinetic runs (up to $15 \%$ ). The results of the absolute measurements of $k_{1}$ are shown in Table 1 . The measurements of $k_{1}$ at $\mathrm{T} \geq 360 \mathrm{~K}$ have been conducted in an uncoated quartz reactor and those between 225 and $320 \mathrm{~K}$ in a Pyrex reactor coated with halocarbon wax. The combined uncertainty on $k_{1}$ was estimated 
to be about $15 \%$ by adding in quadrature statistical error $(\leq 5 \%)$ and those on the measurements of the absolute concentration of methanol ( 10\%), flows (3\%), pressure (2\%), temperature (1\%).

The possible impact of secondary chemistry on the measurements of $k_{1}$ can be discussed. Firstly, it should be noted that thermal decomposition of methanol is negligible in the temperature range of the present work. Lu et al. ${ }^{30}$ in their shock tube study reported the rate constant of $3.2 \times 10^{-9} \exp (-29470 / T) \mathrm{cm}^{3}$ molecule $^{-1} \mathrm{~s}^{-1}$ for the thermal decomposition of $\mathrm{CH}_{3} \mathrm{OH}$ at $\mathrm{T}=1660-2050 \mathrm{~K}$. Extrapolation of this expression to $950 \mathrm{~K}$, the highest temperature of the present study, provides the rate constant of $\sim 10^{-22} \mathrm{~cm}^{3}$ molecule $\mathrm{s}^{-1}$, which is too low to affect the measurements of $k_{1}$. Secondary reactions involving $\mathrm{CH}_{2} \mathrm{OH}$ radical formed in reaction (1a) can lead both to production and consumption of $\mathrm{Cl}$ atoms in reactions of $\mathrm{CH}_{2} \mathrm{OH}$ with $\mathrm{Cl}_{2}$ (precursor of $\mathrm{Cl}$ ) and $\mathrm{Cl}$, respectively:

$$
\begin{array}{lll}
\mathrm{Cl}+\mathrm{CH}_{3} \mathrm{OH} & \rightarrow & \mathrm{CH}_{2} \mathrm{OH}+\mathrm{HCl} \\
\mathrm{CH}_{2} \mathrm{OH}+\mathrm{Cl}_{2} & \rightarrow & \mathrm{CH}_{2} \mathrm{ClOH}+\mathrm{Cl} \\
\mathrm{CH}_{2} \mathrm{OH}+\mathrm{Cl} & \rightarrow & \mathrm{CH}_{2} \mathrm{O}+\mathrm{HCl}
\end{array}
$$

The possible reproduction of $\mathrm{Cl}$ atoms in reaction (5) $\left(k_{5}=(2.9 \pm 0.6) \times 10^{-11} \mathrm{~cm}^{3}\right.$ molecule $\mathrm{s}^{-1}$ at $\mathrm{T}=295 \mathrm{~K})^{12}$ is insignificant under experimental conditions of the study due to relatively low concentrations of $\mathrm{Cl}_{2}$ in the reactor, $[\mathrm{Cl}]_{2}=(2-4) \times 10^{11}$ molecule $\mathrm{cm}^{-3}$. In order to experimentally confirm this fact, we have carried out the measurements of $k_{1}$ in the presence of $\mathrm{O}_{2}\left(\approx 2 \times 10^{14}\right.$ molecule $\left.\mathrm{cm}^{-3}\right)$ in the reactor. In the presence of $\mathrm{O}_{2}, \mathrm{CH}_{2} \mathrm{OH}$ radicals are rapidly scavenged via reaction $(2)\left(k_{2}=(9.1 \pm 2.7) \times 10^{-12} \mathrm{~cm}^{3}\right.$ molecule $\mathrm{s}^{-1}$ at $\left.\mathrm{T}=298 \mathrm{~K}\right):^{31}$

$$
\mathrm{CH}_{2} \mathrm{OH}+\mathrm{O}_{2} \quad \rightarrow \quad \mathrm{CH}_{2} \mathrm{O}+\mathrm{HO}_{2}
$$

Figure S3 (SI) demonstrates the second-order plot measured for reaction (1) at $\mathrm{T}=440 \mathrm{~K}$. As one can see, the results of the measurements of $k_{1}{ }^{\prime}$ in the presence and in the absence of $\mathrm{O}_{2}$ in the reactor are indistinguishable within the experimental error, which indicates a negligible role of reaction (5) under the experimental conditions of the measurements of $k_{1}$. Among the data presented in Table 1 , those at $\mathrm{T}=360$ and $770 \mathrm{~K}$ were obtained in the presence of $\mathrm{O}_{2}$ in the reactor.

To our knowledge the rate constant of reaction (6) was reported in two studies at room temperature: $k_{6}=1.4 \times 10^{-1032}$ and $6.64 \times 10^{-10} \mathrm{~cm}^{3}$ molecule $\mathrm{e}^{-1} \mathrm{~s}^{-13}$ The last, rather high, value of $k_{6}$ was extracted from the simulation of the experimental profiles $\mathrm{Cf}^{\mathrm{C}} \mathrm{H}_{2} \mathrm{OH}$ observed 
upon the pulse radiolysis of $\mathrm{SF}_{6} / \mathrm{HCl} / \mathrm{CH}_{3} \mathrm{OH}$ mixtures. ${ }^{33}$ With $k_{6}$ as high as $6.6 \times 10^{-10} \mathrm{~cm}^{3}$ molecule $\mathrm{e}^{-1} \mathrm{~s}^{-1}$, in the present experiments, the contribution of the secondary reaction of $\mathrm{Cl}$ with $\mathrm{CH}_{2} \mathrm{OH}$ to the measured $\mathrm{Cl}$ decays would be significant, especially at low concentrations of methanol. This would lead to increase of the intercepts in the second-order plots shown in Figure 2. In fact, this was not the case: the intercepts of the second-order plots were always in good agreement with the values of $k_{\mathrm{w}}$ measured in the absence of $\mathrm{CH}_{3} \mathrm{OH}$ in the reactor, as shown in Figure 2. Experiments with addition of $\mathrm{O}_{2}$ into reactive system (see above) also seem to indicate that impact of reaction (6) is insignificant. In the presence of $\mathrm{O}_{2}$, $\mathrm{CH}_{2} \mathrm{OH}$ is transformed via reaction (2) into $\mathrm{CH}_{2} \mathrm{O}$ and $\mathrm{HO}_{2}$, which are less reactive toward $\mathrm{Cl}$ atom compared with $\mathrm{CH}_{2} \mathrm{OH}\left(k_{7}=4.3 \times 10^{-11}\right.$ and $k_{8}=8.1 \times 10^{-11} \exp (-30 / \mathrm{T}) \mathrm{cm}^{3}$ molecule $^{-1} \mathrm{~s}^{-1}$ at $T=230-420$ and $200-500 \mathrm{~K}$, respectively): ${ }^{31}$

$$
\begin{array}{ll}
\mathrm{Cl}+\mathrm{HO}_{2} \rightarrow & \text { products } \\
\mathrm{Cl}+\mathrm{CH}_{2} \mathrm{O} \rightarrow & \mathrm{HCO}+\mathrm{HCl}
\end{array}
$$

For complete confidence in the minor role of the secondary chemistry in the absolute measurements of $k_{1}$, we have carried out relative rate measurements under conditions where secondary reactions (5) and (6) are obviously not important.

\subsection{Rate constant of reaction (1): relative measurements}

In the relative measurements of $k_{1}$, reaction of $\mathrm{Cl}$ atoms with $\mathrm{Br}_{2}$ was used as a reference. The experiments consisted in a fast consumption of $\mathrm{Cl}$ in reaction with a mixture of $\mathrm{Br}_{2}$ and $\mathrm{CH}_{3} \mathrm{OH}$ and the measurements of $\mathrm{BrCl}$ yield as a function of the $\left[\mathrm{CH}_{3} \mathrm{OH}\right] /\left[\mathrm{Br}_{2}\right]$ ratio:

$$
\begin{array}{lll}
\mathrm{Cl}+\mathrm{CH}_{3} \mathrm{OH} & \rightarrow & \text { products } \\
\mathrm{Cl}+\mathrm{Br}_{2} & \rightarrow & \mathrm{BrCl}+\mathrm{Br}
\end{array}
$$

The fraction of the initial concentration of $\mathrm{Cl}$ atoms, $[\mathrm{Cl}]_{0}$, transformed to $\mathrm{BrCl}$ in reaction 3, is:

$$
[\mathrm{BrCl}]=\frac{k_{3}\left[\mathrm{Br}_{2}\right]}{k_{3}\left[\mathrm{Br}_{2}\right]+k_{1}\left[\mathrm{CH}_{3} \mathrm{OH}\right]+k_{w}} \times[\mathrm{Cl}]_{0}
$$

After rearrangement of this expression one has:

$$
\frac{[\mathrm{Cl}]_{0}}{[\mathrm{BrCl}]}-1=\frac{k_{1}\left[\mathrm{CH}_{3} \mathrm{OH}\right]}{k_{3}\left[\mathrm{Br}_{2}\right]}+\frac{k_{W}}{k_{3}\left[\mathrm{Br}_{2}\right]}
$$

At a constant concentration of $\mathrm{Br}_{2}$, the second term in equation (I) is constant and $k_{1} / k_{3}$ can be determined as a slope of the linear dependence of $\left([\mathrm{Cl}]_{0} /[\mathrm{BrCl}]-1\right)$ on the $\left[\mathrm{CH}_{3} \mathrm{OH}\right] /\left[\mathrm{Br}_{2}\right]$ ratio. In the experiments, $\mathrm{BrCl}$ was monitored in both $\mathrm{CH}_{3} \mathrm{OH}$-free system, corresponding to 
$[\mathrm{Cl}]_{0}$, and in the $\mathrm{Br}_{2}$ and $\mathrm{CH}_{3} \mathrm{OH}$-containing system, corresponding to the fraction of $[\mathrm{Cl}]_{0}$ reacted with $\mathrm{Br}_{2}$. Reaction time was $(0.012-0.017) \mathrm{s},[\mathrm{Cl}]_{0}=(2-5) \times 10^{11}$ molecule $\mathrm{cm}^{-3}$, concentrations of $\mathrm{CH}_{3} \mathrm{OH}$ and $\mathrm{Br}_{2}$ are shown in Table 2. The relative measurements of $k_{1}$ were carried out in an uncoated quartz reactor, except $\mathrm{T}=227,243$ and $295 \mathrm{~K}$, where the reactor coated with halocarbon wax was used. Typical examples of the experimental data are shown in Figure 3. Final values of $k_{1}$ (Table 2) were calculated with $k_{3}=1.64 \times 10^{-10}$ $\exp (34 / \mathrm{T}) \mathrm{cm}^{3}$ molecule $\mathrm{s}^{-1}$ determined in this study with conservative $15 \%$ uncertainty at all temperatures $(T=225-960 K)$.

One can note that the results of the relative measurements are in excellent agreement with the absolute measurements of $k_{1}$. It should be emphasized that secondary reactions (5) and (6) are not operative under the experimental conditions of the relative measurements. Firstly, in the presence of high concentrations of $\mathrm{Br}_{2}$ and $\mathrm{CH}_{3} \mathrm{OH}, \mathrm{Cl}$ atoms are rapidly titrated in primary reactions (1) and (3). Secondly, $\mathrm{CH}_{2} \mathrm{OH}$ radical is expected to be rapidly scavenged by $\mathrm{Br}_{2}\left(\left[\mathrm{Br}_{2}\right]>>\left[\mathrm{Cl}_{2}\right]\right)$ :

$$
\mathrm{CH}_{2} \mathrm{OH}+\mathrm{Br}_{2} \quad \rightarrow \quad \mathrm{CH}_{2} \mathrm{BrOH}+\mathrm{Br}
$$

Although the rate constant of reaction (9) is unknown, it is expected to be higher than $k_{5}$ by analogy with reactions of $\mathrm{Br}_{2}$ and $\mathrm{Cl}_{2}$ with other organic radicals.

It can also be noted that reaction of $\mathrm{CH}_{3} \mathrm{OH}$ with $\mathrm{Br}$ atoms formed in reactions (1) and $(9)::^{34}$

$$
\begin{aligned}
& \mathrm{Br}+\mathrm{CH}_{3} \mathrm{OH} \rightarrow \mathrm{CH}_{2} \mathrm{OH}+\mathrm{HBr} \\
& k_{10}=5.66 \times 10^{-15}(\mathrm{~T})^{1.5} \exp (-3600 / \mathrm{T}) \mathrm{cm}^{3} \text { molecule }^{-1} \mathrm{~s}^{-1}(\mathrm{~T}=439-713 \mathrm{~K})
\end{aligned}
$$

is relatively slow, and, in any case, has a negligible impact on the concentrations of $\mathrm{CH}_{3} \mathrm{OH}$, considering that $\left[\mathrm{CH}_{3} \mathrm{OH}\right]>>[\mathrm{Br}] \sim[\mathrm{Cl}]_{0}$.

\subsection{Rate constant of reaction (3)}

The rate constant of reaction (3) was determined from $\mathrm{Cl}$ decays $\left([\mathrm{Cl}]_{0}=(0.5-1.5) \times 10^{11}\right.$ molecule $\mathrm{cm}^{-3}$ ) monitored in excess of $\mathrm{Br}_{2}$ (Table 3). Examples of the kinetics of $\mathrm{Cl}$ consumption observed at different concentrations of $\mathrm{Br}_{2}$ are shown in Figure S4 (SI). The consumption of $\mathrm{Br}_{2}$ was generally within a few percent: only in a few measurements (at lowest concentrations of $\mathrm{Br}_{2}$ ) it was significantly higher (up to $25 \%$ ). The reaction rate constant was always calculated using the mean concentration of $\mathrm{Br}_{2}$ along the reaction zone. 
Typical plots of the pseudo-first-order rate constant, $k_{3}{ }^{\prime}=k_{3} \times\left[\mathrm{Br}_{2}\right]+k_{\mathrm{w}}$, versus concentration of $\mathrm{Br}_{2}$ are shown in Figure 4. Diffusion corrections on $k_{3}{ }^{\prime}$ were usually less than $10 \%$ and up to $16 \%$ in a few kinetic runs. The $\mathrm{Y}$-intercepts of all the second-order plots, $k_{\mathrm{w}}$, were in the range $(0-22) \mathrm{s}^{-1}$, in good agreement with the rate of $\mathrm{Cl}$ decay measured in the absence of $\mathrm{Br}_{2}$ in the reactor. All the results of the absolute measurements of $k_{3}$ (with estimated total uncertainty on $k_{3}$ of $\approx 15 \%$ ) are shown in Table 3 . At $\mathrm{T} \leq 320$ and $\geq 340 \mathrm{~K}$, the measurements were carried out in a Pyrex reactor coated with halocarbon wax and in an uncoated quartz reactor, respectively.

\subsection{Comparison with previous studies}

Figure 5 summarizes the results of the measurements of the rate constant of reaction (3). In earlier room temperature discharge-flow studies using $\mathrm{Cl}$ detection by atomic resonance fluorescence, the values of $k_{3}=(1.20 \pm 0.15) \times 10^{-10} 19$ and $(1.9 \pm 0.2) \times 10^{-10} \mathrm{~cm}^{3}$ molecule $\mathrm{s}^{-1}$ ${ }^{20}$ were reported at $\mathrm{T}=298 \mathrm{~K}$. The difference between two values measured with the same method and in the same group was explained ${ }^{20}$ by $\mathrm{Br}_{2}$ loss in the flowmeter when passing a dilute mixture of $\mathrm{Br}_{2}$ with inert gas, leading to an underestimation of $k_{3}$ in the study of Clyne and Cruse. ${ }^{19}$ Nicovich and Wine ${ }^{21}$ employed a laser flash photolysis-resonance fluorescence technique to measure the rate constant of reaction (3) as a function of temperature at $T=$ 298-401 K. $k_{3}=(1.58 \pm 0.22) \times 10^{-10} \mathrm{~cm}^{3}$ molecule $\mathrm{s}^{-1} \mathrm{~s}^{-1}$ was found to be virtually independent of temperature, although a slight positive temperature dependence was observed $(E / R=144$ K). ${ }^{21}$ The $k_{3}$ data of Nicovich and Wine ${ }^{21}$ shown in Figure 5 have been adjusted upward by $11 \%$, as proposed by Khamaganov and Crowley, ${ }^{23}$ considering currently recommended ${ }^{31}$ absorption cross section for $\mathrm{Br}_{2}$ at $415.8 \mathrm{~nm}$ of $6.5 \times 10^{-19} \mathrm{~cm}^{2}$ molecule ${ }^{-1}$ instead of $5.87 \times$ $10^{-19} \mathrm{~cm}^{2}$ molecule ${ }^{-1}$ used by Nicovich and Wine ${ }^{21}$ in optical measurements of the $\mathrm{Br}_{2}$ concentrations. In previous study from our group, ${ }^{22}$ essentially similar (to those of the present work) experimental equipment and experimental approach were used except that $\mathrm{Cl}$ atoms were titrated at the end of the reactor with $\mathrm{C}_{2} \mathrm{H}_{3} \mathrm{Br}$ to be monitored at $\mathrm{m} / \mathrm{z}=62 / 64$ $\left(\mathrm{C}_{2} \mathrm{H}_{3} \mathrm{Cl}^{+}\right)$:

$$
\mathrm{Cl}+\mathrm{C}_{2} \mathrm{H}_{3} \mathrm{Br} \quad \rightarrow \quad \mathrm{Br}+\mathrm{C}_{2} \mathrm{H}_{3} \mathrm{Cl}
$$

As one can see in Figure 5, the values of $k_{3}$ from the earlier study ${ }^{22}$ are by up to $30 \%$ lower than those measured in the present work. The reason for this disagreement is most likely due to a systematic error in previous measurements, which is difficult to identify at present. 
Khamaganov and Crowley ${ }^{23}$ measured the rate coefficient of the $\mathrm{Cl}+\mathrm{Br}_{2}$ reaction, $\mathrm{k}_{3}=(1.94 \pm$ $0.12) \times 10^{-10} \mathrm{~cm}^{3}$ molecule $\mathrm{s}^{-1}$ at $\mathrm{T}=298 \mathrm{~K}$, using laser-pulsed photolysis of $\mathrm{Cl}_{2}$ in the presence of $\mathrm{Br}_{2}$ with detection of the reaction product, $\mathrm{Br}$ atoms, using resonance fluorescence. $\mathrm{A}$ limited data set obtained by the authors at $228 \mathrm{~K}$ provided $k_{3}=(2.1 \pm 0.3) \times 10^{-10} \mathrm{~cm}^{3}$ molecule $e^{-1} s^{-1}$ at this temperature. Khamaganov and Crowley ${ }^{23}$ combined their data with those of Nicovich and Wine ${ }^{21}$ (corrected for absorption cross section) and recommended a value of $k_{3}=(1.81 \pm 0.10) \times 10^{-10} \mathrm{~cm}^{3}$ molecule $\mathrm{e}^{-1} \mathrm{~s}^{-1}$, independent of temperature from 200 to $400 \mathrm{~K}$. This value is in excellent agreement with the mean of all the measurements of $k_{3}$ carried out in the present study, $k_{3}( \pm 1 \sigma)=(1.8 \pm 0.1) \times 10^{-10} \mathrm{~cm}^{3}$ molecule ${ }^{-1} \mathrm{~s}^{-1}$ at $\mathrm{T}=225$ 960K (dotted line in Figure 5), although we observe a slight decrease of the rate constant with increasing temperature. Least-squares fit to $k_{3}$ data from the present work (solid line in Figure 5) provides the following Arrhenius expression:

$$
k_{3}=1.64 \times 10^{-10} \exp (34 / \mathrm{T}) \mathrm{cm}^{3} \text { molecule }^{-1} \mathrm{~s}^{-1} \text { at } \mathrm{T}=225-960 \mathrm{~K} \text {. }
$$

The dashed lines in Figure 5 correspond to $\pm 15 \%$ deviation from this expression, showing that practically all temperature dependent data for $k_{3}$ (except earlier measurements from this group $)^{22}$ fall into this range. Based on this, we would recommend the above expression for $k_{3}$ for use in the temperature range $225-960 \mathrm{~K}$ with conservative $15 \%$ uncertainty. The observed small negative temperature dependence of $k_{3}$ may be considered as an indication of a complex reaction mechanism that includes formation of an intermediate energized complex followed either by its dissociation back to reactants or to reaction products.

The results of room temperature measurements of ${k_{1}}^{7-15}$ (summarized, for instance, in ref. 18), employing various experimental techniques and both absolute and relative rate methods, are consistent with each other and fall in the range $(4.57-6.14)) \times 10^{-11} \mathrm{~cm}^{3}$ molecule $\mathrm{e}^{-1} \mathrm{~s}^{-1}$ with an average value of $k_{1}( \pm 2 \sigma)=(5.35 \pm 0.90) \times 10^{-11} \mathrm{~cm}^{3}$ molecule $^{-1} \mathrm{~s}^{-1}$ at $\mathrm{T}=$ $298 \mathrm{~K}$. The available temperature dependent $k_{1}$ data ${ }^{6,16-18}$ are shown in Figure 6 along with the results of the present work. The first determination of the rate constant of reaction (1) was realized by Michael et al. ${ }^{6}$ using the flash photolysis-resonance fluorescence technique. The reaction rate constant was found to be $k_{1}( \pm 1 \sigma)=(6.33 \pm 0.70) \times 10^{-11} \mathrm{~cm}^{3}$ molecule $\mathrm{e}^{-1}$ independent of temperature over the range 200-500 K. In contrast, Garzón et al. ${ }^{16}$ in their laser photolysis-resonance fluorescence study of reaction (1) reported significant temperature dependence for $k_{1}$ at $\left.\mathrm{T}=266-380 \mathrm{~K}: k_{1}=(3.55 \pm 0.22) \times 10^{-10} \exp (-559 \pm 40) / \mathrm{T}\right) \mathrm{cm}^{3}$ 
molecule ${ }^{-1} s^{-1}$. Kaiser and Wallington ${ }^{17}$ employed relative rate technique with $\mathrm{C}_{2} \mathrm{H}_{6}$ as the reference compound and reported a weaker temperature dependence over the temperature range $\left.291-475 \mathrm{~K}: k_{1}=(8.6 \pm 1.3) \times 10^{-11} \exp (-167 \pm 60) / \mathrm{T}\right) \mathrm{cm}^{3}$ molecule $^{-1} \mathrm{~s}^{-1}$. Finally in a most recent study of Hui et al., ${ }^{18}$ the rate constant of reaction (1) was determined from the kinetics of $\mathrm{HO}_{2}$ formation upon pulsed laser photolysis of $\mathrm{Cl}_{2}$ in presence of $\mathrm{CH}_{3} \mathrm{OH}$ and $\mathrm{O}_{2}: k_{1}$ $\left.=(5.02 \pm 1.5) \times 10^{-11} \exp (20 \pm 88) / \mathrm{T}\right) \mathrm{cm}^{3}$ molecule $\mathrm{e}^{-1} \mathrm{~s}^{-1}$ over the range $\mathrm{T}=230-297 \mathrm{~K}$. Within experimental uncertainty, the rate constant was temperature independent with the average value of $k_{1}=(5.45 \pm 0.37) \times 10^{-11} \mathrm{~cm}^{3}$ molecule $\mathrm{s}^{-1}$ over this temperature range.

As one can see in Figure 6 , on the absolute basis the $k_{1}$ data from the present work are in agreement within stated experimental uncertainties with all the previous temperature dependent measurements, except a few points from Garzón et al. ${ }^{16}$ The present data obtained in a wide temperature range seem to definitely confirm the temperature independence of $k_{1}$ reported in previous studies of Michael et al. ${ }^{6}$ and Hui et al. ${ }^{18}$ and question quite a strong temperature dependence of $k_{1}$ measured by Garzón et al. ${ }^{16}$ The observed independence of $k_{1}$ of temperature is in line with empirical correlations between the $\mathrm{R}-\mathrm{H}$ bond energy and corresponding temperature dependence of the $\mathrm{H}$-atom abstraction by $\mathrm{Cl}^{6,7,18}$ and with theoretical calculations of $k_{1}$ in the range $\mathrm{T}=300-1000 \mathrm{~K}$ shown in Figure 6 by dotted line. ${ }^{35}$ Solid line in Figure 6 corresponds to the mean value of $k_{1}$ from the present measurements at all temperatures which is recommended from this study with conservative 15\% uncertainty (dashed lines):

$$
k_{1}=(5.1 \pm 0.8) \times 10^{-11} \mathrm{~cm}^{3} \text { molecule } \mathrm{s}^{-1} \text { over the temperature range } 225-950 \mathrm{~K} .
$$

There is an experimental ${ }^{7,36}$ and theoretical ${ }^{35}$ evidence that reaction of $\mathrm{Cl}$-atom with methanol proceeds predominantly through hydrogen atom abstraction from the methyl group (reaction 1a):

$$
\begin{aligned}
& \mathrm{Cl}+\mathrm{CH}_{3} \mathrm{OH} \rightarrow \mathrm{CH}_{2} \mathrm{OH}+\mathrm{HCl} \\
& \mathrm{Cl}+\mathrm{CH}_{3} \mathrm{OH} \rightarrow \mathrm{CH}_{3} \mathrm{O}+\mathrm{HCl}
\end{aligned}
$$

Dóbé et al. ${ }^{36}$ have reported the yield of $\mathrm{CH}_{3} \mathrm{O}$ radical in reaction (1) of $0.01 \pm 0.01$ and $0.04 \pm 0.02$ at $\mathrm{T}=298$ and $482 \mathrm{~K}$, respectively. Theoretical calculations predict nearly $1 \%$ for the branching ratio of the $\mathrm{CH}_{3} \mathrm{O}$ forming channel (1b) at $\mathrm{T}=1000 \mathrm{~K} .{ }^{35}$ In the present work, we have tried to estimate the branching ratio for channel $(1 \mathrm{~b})$ at two temperatures, $T=300$ and $900 \mathrm{~K}$. The experiment consisted in successive titration of the same initial concentration of $\mathrm{Cl}$ atoms with $\mathrm{CH}_{3} \mathrm{OH}$ and $\mathrm{CD}_{3} \mathrm{OH}$ with detection of $\mathrm{HCl}$ formed. In the case of $\mathrm{Cl}$ titration 
with $\mathrm{CH}_{3} \mathrm{OH}$, the concentration of $\mathrm{HCl}$ formed corresponds to the initial concentration of $\mathrm{Cl}$ atoms: $[\mathrm{HCl}]_{\mathrm{CH}_{3} \mathrm{OH}}=[\mathrm{Cl}]_{0}$. $\mathrm{HCl}$, if formed upon titration of $\mathrm{Cl}$ with $\mathrm{CD}_{3} \mathrm{OH}$, should come from the $\mathrm{H}$-atom abstraction from $\mathrm{OH}$ group, and the branching ratio for channel (1b) could be determined as the ratio $[\mathrm{HCl}]_{\mathrm{CD}_{3} \mathrm{OH}} /[\mathrm{HCl}]_{\mathrm{CH}_{3} \mathrm{OH}}$, in a relative way without measurements of the absolute concentrations. Unfortunately, the designed experiments were unsuccessful. At both temperatures ( 300 and $900 \mathrm{~K}$ ), the $\mathrm{HCl}$ signal monitored in $\mathrm{Cl}+\mathrm{CD}_{3} \mathrm{OH}$ system was found to be relatively high and to increase with reaction time, most likely, due to isotopic exchange reactions in the gas phase and on the wall of the reactor. Additional experimental work including a thorough analysis of this phenomenon is necessary in order to measure the branching ratio of the $\mathrm{CH}_{3} \mathrm{O}$ forming channel of reaction (1) which is expected to be very small.

\section{CONCLUSION}

In this work, we investigated the kinetics of the reaction of $\mathrm{Cl}$ atoms with methanol using a discharge flow reactor combined with an electron impact ionization mass spectrometer. The total rate constant of the reaction, $k_{1}=(5.1 \pm 0.8) \times 10^{-11} \mathrm{~cm}^{3}$ molecule ${ }^{-1} \mathrm{~s}^{-1}$, was determined using both absolute and relative rate method for temperatures in the range $225-950 \mathrm{~K}$. Temperature dependence of $k_{1}$, measured over a wide temperature range, seems to harmonize existing experimental data for $k_{1}$ and confirms independence of the rate constant of temperature up to $1000 \mathrm{~K}$ in agreement with theoretical predictions. The temperature dependence of the rate constant of the $\mathrm{Cl}+\mathrm{Br}_{2}$ reaction, measured as a part of this study, $k_{3}$ $=1.64 \times 10^{-10} \exp (34 / \mathrm{T}) \mathrm{cm}^{3}$ molecule $^{-1} \mathrm{~s}^{-1}$ at $\mathrm{T}=225-960 \mathrm{~K}$, and found to be in good agreement with most of the previous low temperature data, was extended to higher temperatures $(\mathrm{T}=960 \mathrm{~K})$.

\section{ACKNOWLEDGMENTS}

This research did not receive any specific grant from funding agencies in the public, commercial, or not-for-profit sectors.

\section{SUPPORTING INFORMATION}


Additional supporting information may be found online in the Supporting Information section at the end of the article. 


\section{REFERENCES}

1. Calvert J, Mellouki A, Orlando J, Pilling M, Wallington T. Mechanisms of atmospheric oxidation of the oxygenates. New York: Oxford University Press; 2011.

2. Jacob DJ, Field BD, Li Q, et al. Global budget of methanol: Constraints from atmospheric observations. J. Geophys. Res.: Atmos. 2005;110:D08303.

3. Spicer CW, Chapman EG, Finlayson-Pitts BJ, et al. Unexpectedly high concentrations of molecular chlorine in coastal air. Nature. 1998;394:353-356.

4. Ravishankara AR. Are chlorine atoms significant tropospheric free radicals? Proc. Natl. Acad. Sci. U. S. A. 2009;106:13639-13640.

5. Raff JD, Njegic B, Chang WL, et al. Chlorine activation indoors and outdoors via surfacemediated reactions of nitrogen oxides with hydrogen chloride. Proc. Natl. Acad. Sci. U. S. A. 2009;106:13647-13654.

6. Michael JV, Nava DF, Payne WA, Stief LJ. Rate constants for the reaction of atomic chlorine with methanol and dimethyl ether from 200 to 500 K. J. Chem. Phys. 1979;70:3652-3656.

7. Payne WA, Brunning J, Mitchell MB, Stief L. Kinetics of the reactions of atomic chlorine with methanol and the hydroxymethyl radical with molecular oxygen at $298 \mathrm{~K}$. Int. J. Chem. Kinet. 1988;20:63-74.

8. Wallington TJ, Skewes LM, Siegl WO, Wu C-H, Japar SM. Gas phase reaction of $\mathrm{Cl}$ atoms with a series of oxygenated organic species at 295 K. Int. J. Chem. Kinet. 1988;20:867-875.

9. Lightfoot PD, Veyret B, Lesclaux R. Flash photolysis study of the methylperoxy + hydroperoxy reaction between 248 and 573 K. J. Phys. Chem. 1990;94:708-714.

10. Nelson L, Rattigan O, Neavyn R, Sidebottom H, Treacy J, Nielsen OJ. Absolute and relative rate constants for the reactions of hydroxyl radicals and chlorine atoms with a series of aliphatic alcohols and ethers at 298 K. Int. J. Chem. Kinet. 1990;22:1111-1126.

11. Dóbé $\mathrm{S}$, Otting $\mathrm{M}$, Temps $\mathrm{F}$, Wagner $\mathrm{HG}$, Ziemer $\mathrm{H}$. Fast flow kinetic studies of the reaction $\mathrm{CH}_{2} \mathrm{OH}+\mathrm{HCl} \leftrightharpoons \mathrm{CH}_{3} \mathrm{OH}+\mathrm{Cl}$. The heat of formation of hydroxymethyl. Ber. Bunsenges. Phys. Chem. 1993;97:877-883.

12. Tyndall GS, Orlando JJ, Kegley-Owen CS, Wallington TJ, Hurley MD. Rate coefficients for the reactions of chlorine atoms with methanol and acetaldehyde. Int. J. Chem. Kinet. 1999;31:776-784.

13. Smith JD, DeSain JD, Taatjes CA. Infrared laser absorption measurements of $\mathrm{HCl}(\mathrm{v}=1)$ production in reactions of $\mathrm{Cl}$ atoms with isobutane, methanol, acetaldehyde, and toluene at 295 K. Chem. Phys. Lett. 2002;366:417-425.

14. Seakins PW, Orlando JJ, Tyndall GS. Rate coefficients and production of vibrationally excited $\mathrm{HCl}$ from the reactions of chlorine atoms with methanol, ethanol, acetaldehyde and formaldehyde. Phys. Chem. Chem. Phys. 2004;6:2224-2229.

15. Taketani $F$, Takahashi $\mathrm{K}$, Matsumi $\mathrm{Y}$, Wallington TJ. Kinetics of the reactions of $\mathrm{Cl} *{ }^{*}\left(\mathrm{P}_{1 / 2}\right)$ and $\left.\mathrm{Cl}^{2}{ }^{2} \mathrm{P}_{3 / 2}\right)$ atoms with $\mathrm{CH}_{3} \mathrm{OH}, \mathrm{C}_{2} \mathrm{H}_{5} \mathrm{OH}, \mathrm{n}-\mathrm{C}_{3} \mathrm{H}_{7} \mathrm{OH}$, and $\mathrm{i}-\mathrm{C}_{3} \mathrm{H}_{7} \mathrm{OH}$ at 295 K. J. Phys. Chem. A. 2005;109:3935-3940.

16. Garzón A, Cuevas CA, Ceacero AA, Notario A, Albaladejo J, Fernández-Gómez M. Atmospheric reactions $\mathrm{Cl}+\mathrm{CH}_{3}-\left(\mathrm{CH}_{2}\right)_{n}-\mathrm{OH}(\mathrm{n}=0-4)$ : A kinetic and theoretical study. J. Chem. Phys. 2006;125:104305.

17. Kaiser EW, Wallington TJ. Rate constant of the reaction of chlorine atoms with methanol over the temperature range 291-475 K. Int. J. Chem. Kinet. 2010;42:113-116.

18. Hui AO, Okumura M, Sander SP. Temperature dependence of the reaction of chlorine atoms with $\mathrm{CH}_{3} \mathrm{OH}$ and $\mathrm{CH}_{3} \mathrm{CHO}$. J. Phys. Chem. A. 2019;123:4964-4972. 
19. Clyne MAA, Cruse HW. Atomic resonance fluorescence spectrometry for the rate constants of rapid bimolecular reactions. Part 2.- Reactions $\mathrm{Cl}+\mathrm{BrCl}, \mathrm{Cl}+\mathrm{Br}_{2}, \mathrm{Cl}+\mathrm{ICl}, \mathrm{Br}+\mathrm{IBr}, \mathrm{Br}+\mathrm{ICl}$. J. Chem. Soc., Faraday Trans. 2. 1972;68:1377-1387.

20. Bemand PP, Clyne MAA. Atomic resonance fluorescence spectrometry for rate constants of rapid bimolecular reactions. Part 4.-Chlorine atom fluorescence $4 \mathrm{~s}^{2,4} \mathrm{P}-3 \mathrm{p}^{52} \mathrm{P}$. J. Chem. Soc., Faraday Trans. 2. 1975;71:1132-1144.

21. Nicovich $\mathrm{JM}$, Wine $\mathrm{PH}$. Kinetics of the reactions of $\mathrm{O}\left({ }^{3} \mathrm{P}\right)$ and $\left.\mathrm{Cl}^{2} \mathrm{P}\right)$ with $\mathrm{HBr}$ and $\mathrm{Br}_{2}$. Int. J. Chem. Kinet. 1990;22:379-397.

22. Bedjanian $\mathrm{Y}$, Laverdet $\mathrm{G}$, Le Bras $\mathrm{G}$. Low-pressure study of the reaction of $\mathrm{Cl}$ atoms with isoprene. J. Phys. Chem. A. 1998;102:953-959.

23. Khamaganov $\mathrm{V}$, Crowley JN. Rate coefficients for the reactions $\mathrm{CH}_{3}+\mathrm{Br}_{2}(224-358 \mathrm{~K}), \mathrm{CH}_{3} \mathrm{CO}$ $+\mathrm{Br}_{2}(228$ and $298 \mathrm{~K})$, and $\mathrm{Cl}+\mathrm{Br}_{2}(228$ and $298 \mathrm{~K})$. Int. J. Chem. Kinet. 2010;42:575-585.

24. Riffault $\mathrm{V}$, Bedjanian $\mathrm{Y}$, Le Bras $\mathrm{G}$. Kinetics and mechanism of the reaction of $\mathrm{Cl}$ atoms with $\mathrm{HO}_{2}$ radicals. Int. J. Chem. Kinet. 2001;33:317-327.

25. Riffault $\mathrm{V}$, Bedjanian $\mathrm{Y}$, Le Bras $\mathrm{G}$. Kinetic and mechanistic study of the $\mathrm{X}$ and $\mathrm{XO}(\mathrm{X}=\mathrm{Cl}, \mathrm{Br})$ reactions with dimethyl sulfoxide. Phys. Chem. Chem. Phys. 2003;5:2828-2835.

26. Morin J, Romanias MN, Bedjanian Y. Experimental study of the reactions of $\mathrm{OH}$ radicals with propane, $\mathrm{n}$-pentane, and $\mathrm{n}$-heptane over a wide temperature range. Int. J. Chem. Kinet. 2015;47:629-637.

27. Bedjanian $Y$, LeBras $G$, Poulet $G$. Rate constants for the reactions $\mathrm{I}+\mathrm{OClO}, \mathrm{I}+\mathrm{ClO}, \mathrm{Cl}+\mathrm{I}_{2}$, and $\mathrm{Cl}+\mathrm{IO}$ and heat of formation of IO radicals. J. Phys. Chem. 1996;100:15130-15136.

28. Kaufman F. Kinetics of elementary radical reactions in the gas phase. J. Phys. Chem. 1984;88:4909-4917.

29. Tang MJ, Cox RA, Kalberer M. Compilation and evaluation of gas phase diffusion coefficients of reactive trace gases in the atmosphere: volume 1. Inorganic compounds. Atmos. Chem. Phys. 2014;14:9233-9247.

30. Lu K-W, Matsui H, Huang C-L, Raghunath P, Wang N-S, Lin MC. Shock tube study on the thermal decomposition of $\mathrm{CH}_{3} \mathrm{OH}$. J. Phys. Chem. A. 2010;114:5493-5502.

31. Burkholder JB, Sander SP, Abbatt J, et al. Chemical kinetics and photochemical data for use in atmospheric studies, evaluation No. 18, JPL publication 15-10, Jet Propulsion Laboratory. 2015; http://jpldataeval.jpl.nasa.gov. Accessed January 2020.

32. Grotheer $\mathrm{H}-\mathrm{H}$, Riekert $\mathrm{G}$, Meier $\mathrm{U}$, Just T. Kinetics of the reactions of $\mathrm{CH}_{2} \mathrm{OH}$ radicals with $\mathrm{O}_{2}$ and $\mathrm{HO}_{2}$. Ber. Bunsenges. Phys. Chem. 1985;89:187-191.

33. Pagsberg P, Munk J, Sillesen A, Anastasi C. UV spectrum and kinetics of hydroxymethyl radicals. Chem. Phys. Lett. 1988;146:375-381.

34. Dóbé $\mathrm{S}$, Bérces $\mathrm{T}$, Turányi $\mathrm{T}$, et al. Direct kinetic studies of the reactions $\mathrm{Br}+\mathrm{CH}_{3} \mathrm{OH}$ and $\mathrm{CH}_{2} \mathrm{OH}+\mathrm{HBr}$ : The heat of formation of $\mathrm{CH}_{2} \mathrm{OH}$. J. Phys. Chem. 1996;100:19864-19873.

35. Jodkowski JT, Rayez M-T, Rayez J-C, Bérces T, Dóbé S. Theoretical study of the kinetics of the hydrogen abstraction from methanol. 2. Reaction of methanol with chlorine and bromine atoms. J. Phys. Chem. A. 1998;102:9230-9243.

36. Dóbé $S$, Bérces $T$, Temps F, Wagner HG, Ziemer H. Formation of methoxy and hydroxymethyl free radicals in selected elementary reactions. Symposium (International) on Combustion. 1994;25:775-781. 


\section{TABLES LEGENDS}

TABLE 1 Reaction $\mathrm{Cl}+\mathrm{CH}_{3} \mathrm{OH}$ : summary of the absolute measurements of the rate constant

TABLE 2 Reaction $\mathrm{Cl}+\mathrm{CH}_{3} \mathrm{OH}$ : summary of the relative measurements of the rate constant

TABLE 3 Reaction $\mathrm{Cl}+\mathrm{Br}_{2}$ : summary of the measurements of the rate constant 


\section{TABLES}

TABLE 1 Reaction $\mathrm{Cl}+\mathrm{CH}_{3} \mathrm{OH}$ : summary of the absolute measurements of the rate constant

\begin{tabular}{|c|c|c|c|}
\hline$T(\mathrm{~K})$ & Number of kinetic runs & $\begin{array}{c}{\left[\mathrm{CH}_{3} \mathrm{OH}\right]} \\
\left(10^{12} \text { molecule } \mathrm{cm}^{-3}\right)\end{array}$ & $\begin{array}{c}k_{1}^{a} \\
\left(10^{-11} \mathrm{~cm}^{3} \text { molecule }^{-1} \mathrm{~s}^{-1}\right)\end{array}$ \\
\hline $225^{b}$ & 11 & $0.41-10.8$ & 5.17 \\
\hline $245^{b}$ & 7 & $0.78-12.6$ & 4.96 \\
\hline $266^{b}$ & 9 & $0.59-16.0$ & 5.14 \\
\hline $298^{b}$ & 10 & $1.16-17.3$ & 5.11 \\
\hline $320^{b}$ & 10 & $1.79-17.6$ & 5.06 \\
\hline $360^{c, d}$ & 7 & $1.82-13.0$ & 5.10 \\
\hline $440^{c}$ & 12 & $0.76-12.2$ & 5.20 \\
\hline $495^{b}$ & 9 & $0.42-15.5$ & 4.92 \\
\hline $500^{b}$ & 11 & $0.55-15.2$ & 5.01 \\
\hline $560^{c}$ & 13 & $0.81-11.8$ & 5.16 \\
\hline $650^{b}$ & 13 & $0.83-15.4$ & 5.16 \\
\hline $770^{c, d}$ & 9 & $1.00-13.0$ & 5.02 \\
\hline $950^{b}$ & 12 & $0.90-12.7$ & 5.14 \\
\hline \multicolumn{4}{|c|}{$\begin{array}{l}\text { a Statistical uncertainty on } k_{1} \text { is } \leq 5 \% \text {, total estimated uncertainty is nearly } 15 \% \text {; } \\
\text { b } \mathrm{Cl} \text { atoms monitored at } \mathrm{m} / \mathrm{z}=116\left(\mathrm{BrCl}^{+}\right) \text {(see text); }\end{array}$} \\
\hline
\end{tabular}

TABLE 2 Reaction $\mathrm{Cl}+\mathrm{CH}_{3} \mathrm{OH}$ : summary of the relative measurements of the rate constant

$\begin{array}{lccccc}T(\mathrm{~K}) & \text { No./exp. }{ }^{a} & {\left[\mathrm{CH}_{3} \mathrm{OH}\right]^{b}} & {\left[\mathrm{Br}_{2}\right]^{b}} & k_{1} / k_{3}{ }^{c} & k_{1}{ }^{d} \\ 227 & 9 & 0.67-8.68 & 1.34 & 0.264 & 5.03 \\ 243 & 12 & 0.56-9.67 & 1.10 & 0.278 & 5.24 \\ 295 & 11 & 0.65-13.6 & 1.22 & 0.273 & 5.02 \\ 335 & 10 & 0.45-10.5 & 1.36 & 0.279 & 5.06 \\ 355 & 13 & 0.38-8.91 & 1.09 & 0.285 & 5.14 \\ 385 & 9 & 0.38-11.2 & 1.44 & 0.292 & 5.23 \\ 456 & 11 & 0.40-6.77 & 0.62 & 0.282 & 4.98 \\ 600 & 13 & 0.23-5.96 & 1.09 & 0.305 & 5.29 \\ { }^{a} \text { Number of data points; } & & & & \\ { }^{b} \text { Units of } 10^{13} \text { molecule } \mathrm{cm}^{-3} ; & & & \end{array}$


TABLE 3 Reaction $\mathrm{Cl}+\mathrm{Br}_{2}$ : summary of the measurements of the rate constant

\begin{tabular}{|c|c|c|c|}
\hline$T(\mathrm{~K})$ & Number of kinetic runs & $\begin{array}{c}{\left[\mathrm{Br}_{2}\right]} \\
\left(10^{12} \text { molecule } \mathrm{cm}^{-3}\right)\end{array}$ & $\begin{array}{c}k_{3}^{a} \\
\left(10^{-10} \mathrm{~cm}^{3} \text { molecule }^{-1} \mathrm{~s}^{-1}\right)\end{array}$ \\
\hline $225^{b}$ & 10 & $0.71-3.84$ & 1,97 \\
\hline $237^{b}$ & 9 & $0.35-3.53$ & 1,94 \\
\hline $257^{b}$ & 10 & $0.59-4.43$ & 1,80 \\
\hline $280^{b}$ & 9 & $0.69-4.41$ & 1,74 \\
\hline $298^{b}$ & 9 & $0.33-5.02$ & 1,85 \\
\hline $320^{b}$ & 9 & $0.48-4.40$ & 1,87 \\
\hline $340^{b}$ & 9 & $0.54-4.44$ & 1,85 \\
\hline $370^{c}$ & 7 & $0.46-3.78$ & 1,71 \\
\hline $400^{b}$ & 7 & $0.28-3.57$ & 1,87 \\
\hline $440^{b}$ & 6 & $0.29-3.31$ & 1,75 \\
\hline $500^{b}$ & 11 & $0.40-3.62$ & 1,75 \\
\hline $567^{c}$ & 11 & $0.21-3.66$ & 1,74 \\
\hline $650^{b}$ & 7 & $0.20-2.14$ & 1,70 \\
\hline $785^{b}$ & 8 & $0.26-2.17$ & 1,75 \\
\hline $960^{c}$ & 13 & $0.21-3.57$ & 1,70 \\
\hline
\end{tabular}




\section{FIGURE LEGENDS}

FIGURE 1 Reaction $\mathrm{Cl}+\mathrm{CH}_{3} \mathrm{OH}$ : examples of $\mathrm{Cl}$ decay profiles in presence of different amounts of methanol at $\mathrm{T}=560 \mathrm{~K}$.

FIGURE 2 Reaction $\mathrm{Cl}+\mathrm{CH}_{3} \mathrm{OH}$ : plot of pseudo-first-order rate constant $\left(k_{1}{ }^{\prime}\right)$ versus concentration of $\mathrm{CH}_{3} \mathrm{OH}$ at different temperatures. Error bars represent typical uncertainties $(\leq 5 \%)$ on the determination of $k_{1}{ }^{\prime}$. For clarity, the data for $\mathrm{T}=560$ and $950 \mathrm{~K}$ are $Y$-shifted by 100 and $200 \mathrm{~s}^{-1}$, respectively.

FIGURE 3 Yield of $\mathrm{BrCl}$ from $\mathrm{Cl}$-atom titration with $\mathrm{Br}_{2}+\mathrm{CH}_{3} \mathrm{OH}$ mixtures at different temperatures. Partially shown error bars represent typical uncertainties of the measurements $(\leq 10 \%)$. For clarity, the data for $\mathrm{T}=385$ and $600 \mathrm{~K}$ are $Y$-shifted by 0.5 and 1.0 , respectively.

FIGURE 4 Reaction $\mathrm{Cl}+\mathrm{Br}_{2}$ : plot of pseudo-first-order rate constant $\left(k_{3}{ }^{\prime}\right)$ versus concentration of $\mathrm{Br}_{2}$ at different temperatures. Partially shown error bars represent typical uncertainties $(\leq 5 \%)$ on the determination of $k_{3}{ }^{\prime}$.

FIGURE 5 Reaction $\mathrm{Cl}+\mathrm{Br}_{2}$ : summary of the measurements of the temperature dependence of the reaction rate constant. Partially shown for the present data error bars correspond to estimated $15 \%$ uncertainty on the measurements of $k_{3}$. Solid line: Arrhenius fit to the present data; dashed lines: present fit $\pm 15 \%$.

FIGURE 6 Reaction $\mathrm{Cl}+\mathrm{CH}_{3} \mathrm{OH}$ : summary of the temperature dependent measurements of the reaction rate constant. AM: absolute measurement, $\mathrm{RM}$ : relative rate method. The error bars partially shown for the present data correspond to estimated 15 and $20 \%$ uncertainty on the measurements of $k_{1}$ in the present work by absolute and relative rate method, respectively; uncertainties on previous measurements are given as reported in respective studies. 